\title{
Evolution, Impact, and Limitations of Unusual Central Bank Policy Activism
}

\author{
Mohamed A. El-Erian
}

\begin{abstract}
In the United States and Europe, central banks have essentially been the only policymaking entities consistently willing and able to take bold measures to deal with an unusually complex set of national, regional, and global economic and financial challenges since the onset of the Great Recession and financial crisis. The author advocates for other agencies, in both the public and private sectors, to urgently work in conjunction with central bank policies. He states that it is critical that policymakers, business leaders, investors, and researchers alike understand better why so many unthinkable events have become facts, why the outlook remains "unusually uncertain," and what changes are needed to limit the risks of further disruptions and bad surprises down the road. Central banks may find themselves facing one of two extremes: complementing policies by other agencies that put the global economy back on the path of high sustained growth and ample job creation or cleaning up in the midst of a global recession, forced deleveraging, and disorderly debt deflation.
\end{abstract}

Federal Reserve Bank of St. Louis Review, July/August 2012, 94(4), pp. 243-64.

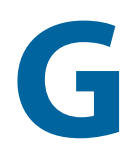
ood afternoon. It is a huge honor for me to be here today. At the outset, I would like to express my deep appreciation to Jim Bullard and colleagues at the Federal Reserve Bank of St. Louis. Thank you for inviting me to such a wonderful event. Thank you for the opportunity to visit this beautiful city and to reconnect with old friends and acquaintances. And thank you for allowing me to be part of this stimulating forum which, over the years, has been an important venue for debating ideas and facilitating agile intellectual interactions.

It is a particular honor to be here today for the annual Homer Jones Memorial Lecture. Mr. Jones made important contributions during his illustrious career-principally here at the St. Louis Fed but also at Brookings Institution, the University of Chicago, the Federal Deposit Insurance Corporation (FDIC), and Rutgers University. He was committed to public policy and

Mohamed A. El-Erian is chief executive officer and co-chief investment officer for Pacific Investment Management Co. LLC (PIMCO). The author thanks his PIMCO colleagues for the wonderful interactions and thought-provoking discussions over many years, with special thanks to those colleagues who offered suggestions and/or comments on this paper, including Francesc Balcells, Andrew Balls, Andy Bosomworth, Rich Clarida, Bill Gross, Scott Mather, Saumil Parikh, Lupin Rahman, Josh Thimons, and Ramin Toloui. This paper is based on the author's Homer Jones Memorial Lecture at the Federal Reserve Bank of St. Louis, April 11, 2012.

(c) 2012, The Federal Reserve Bank of St. Louis. The views expressed in this article are those of the author(s) and do not necessarily reflect the views of the Federal Reserve System, the Board of Governors, or the regional Federal Reserve Banks. This material is used with the permission of PIMCO; the current opinions are those of the author but not necessarily those of PIMCO and such opinions are subject to change without notice. Articles may be reprinted, reproduced, published, distributed, displayed, and transmitted in their entirety if copyright notice, author name(s), and full citation are included. Abstracts, synopses, and other derivative works may be made only with prior written permission of the Federal Reserve Bank of St. Louis. 
displayed leadership skills that are still admired today, some 25 years after his passing. And while I have questioned some of the assumptions that underpinned elements of Mr. Jones's work and policy advocacy over the years, I have nothing but admiration for his willingness to question conventional wisdom and official doctrine, encourage researchers to think outside the box, and engage them in open and stimulating debates.

Speaking of stimulating debates, the views that I will express today have been informed and influenced by the rich intellectual interactions that are conducted at PIMCO, my professional home. I am privileged to work in a place that embodies many of the qualities that Mr. Jones felt should dominate and persist in an institution that takes its analytical research seriously and is committed to getting things right even when this means being an outlier. The views that I will share with you are, of course, my personal ones and should in no way be deemed to reflect those of PIMCO as a firm or those of other people who work there.

I wrestled with many topics in preparation for this event. In the process, I remembered the counsel given to me many years ago by a professor when I was trying to select the subject of my doctoral thesis. He advised me that, in order to maximize the probability of success, I should be guided by two principles: Make sure to cover issues where I know more than those who will be evaluating my work and, in putting everything together, make sure that I mix and match among components that no one in their right mind would ever combine!

I did not listen to this professor's advice back in 1980 and I have not done so today. Indeed, I have gone the other way! And in so doing, I suspect that I will get very close to-and perhaps even cross, though I hope not-that delicate line that every speaker faces and fears: the one that separates courage from stupidity. $\underline{1}$

Today, I will ignore the professor's advice in multiple ways. I will speak in a central bank and to central bankers about the role of their institutions-particularly the Federal Reserve and the European Central Bank (ECB) - in today's highly complex, perplexing, and historically unusual policymaking environment. I will go further and try to link actions to motivations. And, when it comes to implications, I will attempt to put forward questions and hypotheses that, I believe, are critical for the future of the United States and global economies-but for which I, like othershave only partial answers.

I do all this for a reason. I believe that, whether you look at the United States or Europe, central banks have essentially been the only policymaking entities consistently willing and able to take bold measures to deal with an unusually complex set of national, regional, and global economic and financial challenges. In doing so, they have evaluated, to use Federal Reserve Board Chairman Ben Bernanke’s phrase, an "unusually uncertain” outlook²; they have confronted some unknowable cost-benefit equations and related economic and political trade-offs and, in some cases, they have even had to make things up as they went along (including moving way ahead of other government agencies that, frustratingly, have remained on the sidelines).

The result of all this is a global configuration of previously unthinkable monetary policy parameters. While their immediate effects may be known, the longer-term ones are less clear, and yet they are important for the well-being of millions around the world. Moreover, there is already evidence to suggest that the impact could well alter for years some of the behavioral relationships that underpin the traditional formulation and effectiveness of the trio of policies, business plans, and financial investment positioning. Accordingly, it is critical that all of us- 
policymakers, business leaders, investors, and researchers-work to understand why so many unthinkables have become facts, why the outlook remains unusually uncertain, and what changes are needed to limit the risks of further disruptions and bad surprises down the road.

For those who are eager to get to the bottom line of my presentation, let me say right here that the analysis will suggest that central banks can no longer-indeed, should no longer-carry the bulk of the policy burden. This is not a question of willingness or ability. Rather, it is a recognition of the declining effectiveness of central banks' tools in countering deleveraging forces amid impediments to growth that dominate the outlook. It is also about the growing risk of collateral damage and unintended circumstances.

It is high time for other agencies, in both the public and private sectors, to step up to the plate. They should - indeed, must - use their better-suited instruments to help lift impediments to sustainable noninflationary growth and job creation. In other words, it is about improving the prospects for higher economic activity and, therefore, "safe deleveraging."

This is not to say that central banks will no longer have an important role. They will. Specifically, in what may gradually morph into an increasingly bimodal distribution of expected outcomes in some parts of the world (such as Europe), central banks could find themselves in one of two extremes: At one end, they may end up complementing (rather than trying to substitute imperfectly for) policies by other agencies that put the global economy back on the path of high sustained growth and ample job creation. At the other end, they may find themselves having to clean up in the midst of a global recession, forced deleveraging, and disorderly debt deflation.

Finally, there is a real question about how the overall global system will evolve. Most agree that its critical Western core is weakened and multilateralism is challenged. As a result, the system is likely to struggle to (i) accommodate the development breakout phase in systemically important emerging economies and (ii) absorb the deleveraging of finance-dependent advanced countries. What is yet to be seen is whether the outcome will be a bumpy transition to a more multipolar global system or the healing and reassertion of a unipolar one.

\section{THE KEY HYPOTHESIS}

To crystallize our conversation today, allow me to use a very-and I stress very-clumsy sentence to summarize the current state of affairs: In the past three-plus years, central banks have had little choice but to do the unsustainable in order to sustain the unsustainable until others do the sustainable to restore sustainability!

Allow me to translate this purposely awful sentence:

- Central banks have had to innovate and stretch policy tools and mandates, including the use of liquidity facilities and communication, to render less disorderly a set of fundamental multiyear economic and financial realignments.

- While initially successful-indeed, critical to avoid a global depression-the policy stance, both here in the United States and over the Atlantic in Europe, appears now to increasingly involve an unfavorable change in the balance between what Chairman Bernanke has labeled as the benefits, costs, and risks. $\frac{3}{}$ 


\section{Figure 1}

\section{Balance Sheet (as percent of GDP)}

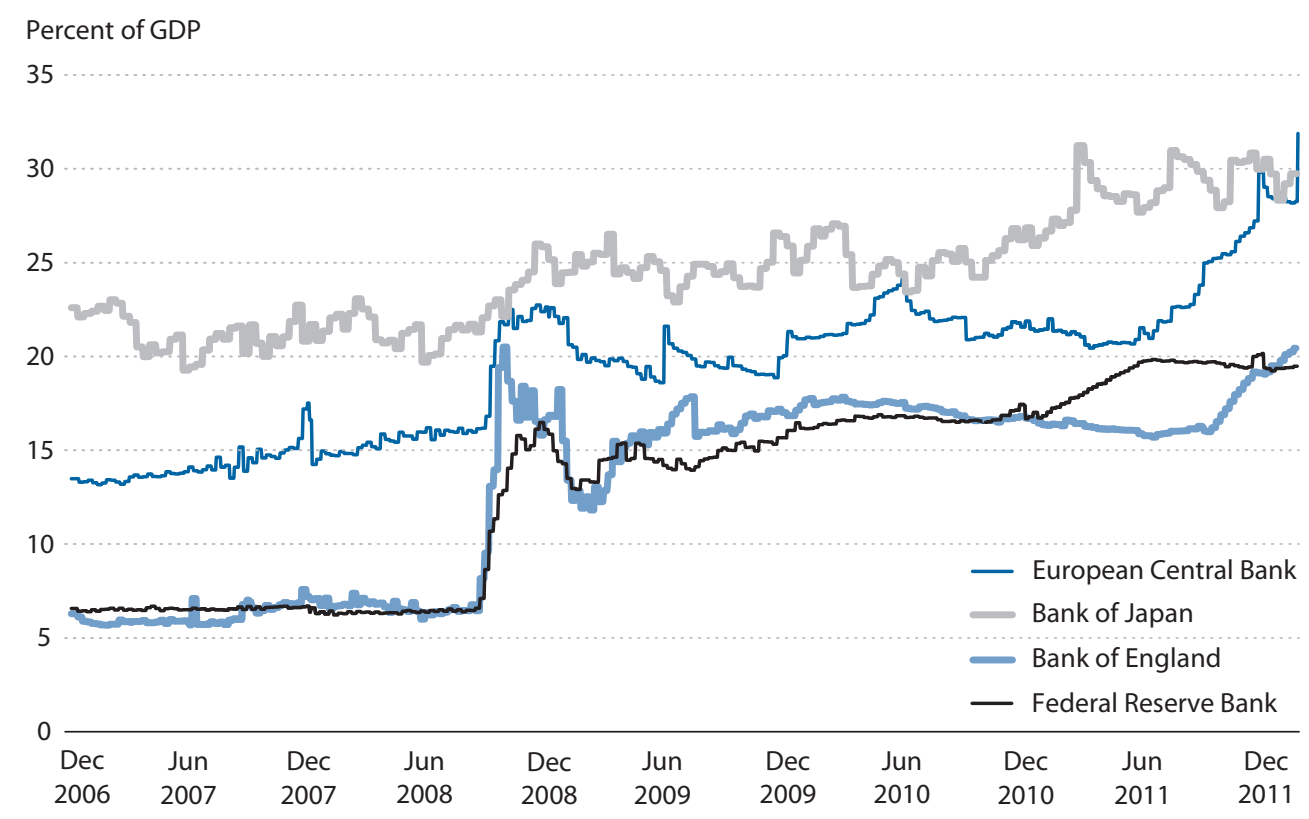

SOURCE: PIMCO, European Central Bank, Bank of England, Federal Reserve, and Bank of Japan.

- Having built a bridge for other policymakers and for healthy balance sheets in the private sector, central banks must now hope that a more timely, comprehensive, and effective response will finally be forthcoming (and push for it, as appropriate).

- Should this fail to materialize, central banks risk finding themselves having built expensive bridges to nowhere and, accordingly, will come under severe pressure with implications for the future of central banking itself, as well as for the welfare of economies at the national, regional, and global levels.

- Meanwhile, the ripple effects from central bank policies will increasingly be felt in the functioning and, in some cases, viability of whole segments of the financial marketsthus adding to the need for both public and private entities to become more intellectually and operationally agile.

\section{A BRIEF AND INCOMPLETE SNAPSHOT OF THE UNUSUAL ACTIVISM OF CENTRAL BANKS}

The best way to get a handle on the unusual activism of central banks is to look at Figure 1 . Central banks in advanced economies have ballooned their balance sheets to previously unthinkable levels-be it an astonishing 20 percent of gross domestic product (GDP) for the Fed or 30 percent for the ECB. 
These unprecedented-indeed, improbable-numbers have been accompanied by other steps also deemed unthinkable not so long ago. In the case of the Fed, the securities purchase program (the second round of quantitative easing [QE2]) has been supplemented by "Operation Twist" and the aggressive use of communication, including signaling that economic conditions "are likely to warrant exceptionally low levels for the federal funds rate at least through late 2014" (Federal Open Market Committee [FOMC] press release, 2012). The FOMC has also disseminated individual members' forecasts for key macro variables and the policy rate (El-Erian, 2012a).

The ECB, not so long ago considered a "Germanic" central bank, has undertaken a range of quasi-fiscal operations-from outright purchases of sovereign bonds under its Securities Markets Programme (SMP), including those subject to material credit/default risk, to a relaxation of collateral requirements and the extension to three years in the maturity of a massive 1 percent "liquidity" facility (the long-term refinancing operations [LTROs]). Having said this, the ECB has been less willing than some other central banks to completely remove credit risk from the market.

In assessing all this, and for presentational simplicity, we can think of the central banks' involvement as two distinct, but of course highly interrelated, operations since the breakout of the global financial crisis in 2007-08. 4 The first entailed crisis management, including minimizing the risk of a liquidity sudden stop ${ }^{5}$ (and related market failures) translating into a major economic depression. The second involved maximizing the prospects for a resumption in growth, employment, and inflation containment. The first dealt primarily with the functioning of markets while the second spoke to targeting economic outcomes. Let us discuss each in turn.

\section{The Context}

The first set of actions, be it the series of emergency facilities activated by the Fed in late 2008-early 2009 or the steps taken by the ECB back then and again more recently, was aimed at breaking the back of a particularly nasty set of multiple equilibria-what Olivier Blanchard, the chief economist at the International Monetary Fund (IMF), described as "self-fulfilling outcomes of pessimism or optimism, with major macroeconomic implications" (Blanchard, 2011).

Think here of the series of path-dependent outcomes that have usually occurred in the debt crises experienced by emerging economies. As shown in a recent paper (El-Erian and Spence, 2012), the underlying dynamics combine endogenous expectation formation with influences on behavior and hence market outcomes. These dynamics are subject to overshoots in the absence of credible circuit breakers. Specifically, a move to a bad (good) outcome increases the probability of a subsequent movement to an even worse (better) situation. It becomes even more difficult for policymakers to agree on the analysis, let alone the solutions. Meanwhile, the social and political costs increase in a nonlinear fashion, making it even harder to recover quickly.

The emphasis in such situations is (i) to boldly break the path-dependent dynamics and (ii) to do so by directing emergency policy measures to address specific market failures as well as strengthening firewalls. General Colin Powell's doctrine is often used here as a guiding principle, including its important qualifier about avoiding costly entanglements via plausible exit strategies alongside a clear intention for such interventions to be both temporary and reversible (see Cohen, 2009). 
El-Erian

\section{Figure 2}

\section{U.S. Unemployment Rate}

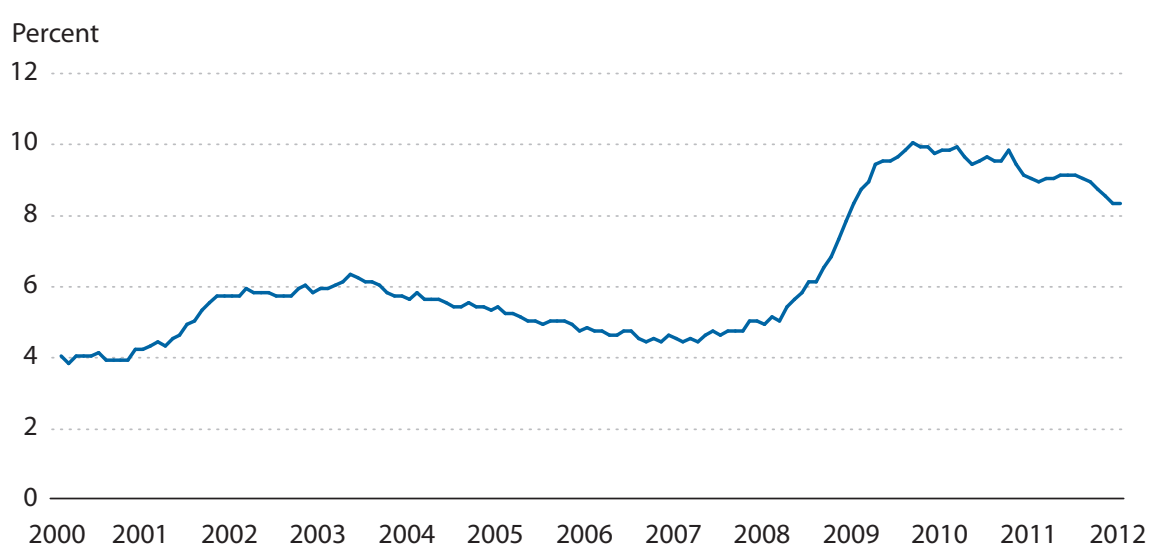

SOURCE: Bureau of Labor Statistics (as of February 29, 2012).

This phase was highly effective in the United States. Think of the Commercial Paper Funding Facility and other measures deployed in the fourth quarter of 2008 and the first quarter of 2009. Starting from a situation where large and multiplying market failures were fueling sudden stops around the world, these policy measures contributed to the return of a more "normal" functioning of markets and, as such, both the disturbance and the policy measures proved largely temporary and reversible, thereby allowing for a handoff back to the private sector.

In Europe, the outcome has been more mixed. The ECB's ample liquidity provisions, and in particular the powerful 3-year LTROs, had a significant impact on bank liquidity and meaningful segments of the sovereign debt markets. Yet they failed to provide a panacea for insolvency risk, exit risk, and insufficient growth. As a result, some market segments remained impaired. Too many participants still preferred to face the ECB as a counterparty, as opposed to facing each other. Moreover, with the debt crisis still ongoing_indeed deepening-and bank fragility not yet eliminated, it is too early to make a definitive assessment.

Now for the experience with the second phase-that aimed at securing certain economic outcomes. In the United States, outcomes have generally been disappointing, both in an absolute sense and, equally importantly, relative to the expectations of policymakers themselves. Just witness the frustrating persistence of unemployment at a very high rate (Figures 2 and 3 ) and the very disturbing long-term component (Figure 4).

As a result, discussion last year about an eventual "exit" from the FOMC's accommodative policy strategy gave way to an intensification of measures aimed at stimulating growth-be it the launch of another round of "unconventional" measures or the unprecedented use of communication. Indeed, as shown in Table 1, the 2011-12 pivot in the FOMC narrative has been quite remarkable.

Interestingly, this pivot was not related to the Fed's ability to influence market valuations in a significant manner and for a substantial period of time. Indeed, the Fed has repeatedly been 


\section{Figure 3}

\section{U.S. Employment (as percent of adult population)}

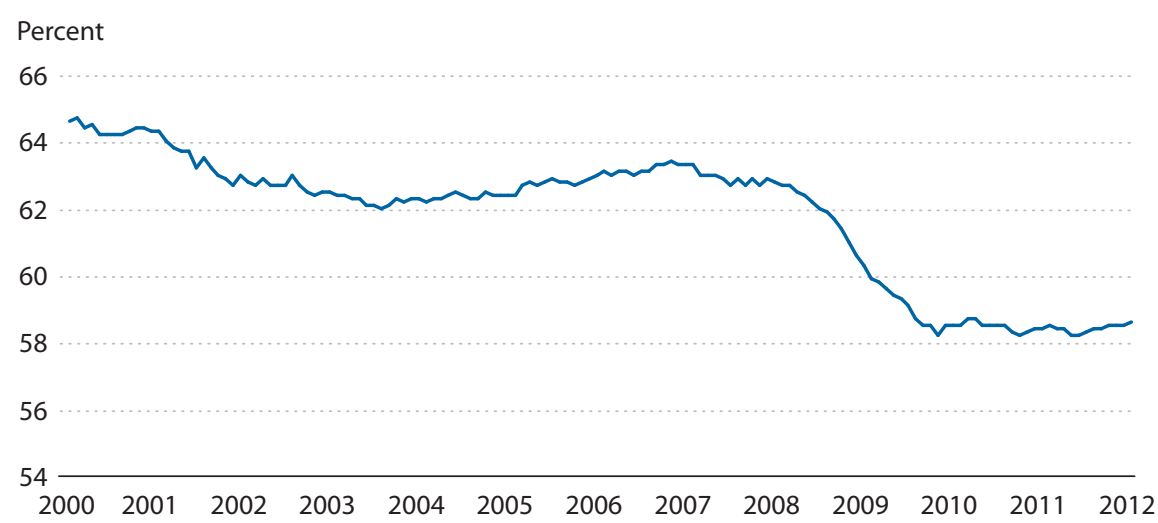

SOURCE: Bureau of Labor Statistics (as of February 29, 2012).

\section{Figure 4}

\section{U.S. Long-Term ( $\geq 27$ Weeks) Unemployment Rate (as percent of unemployed)}

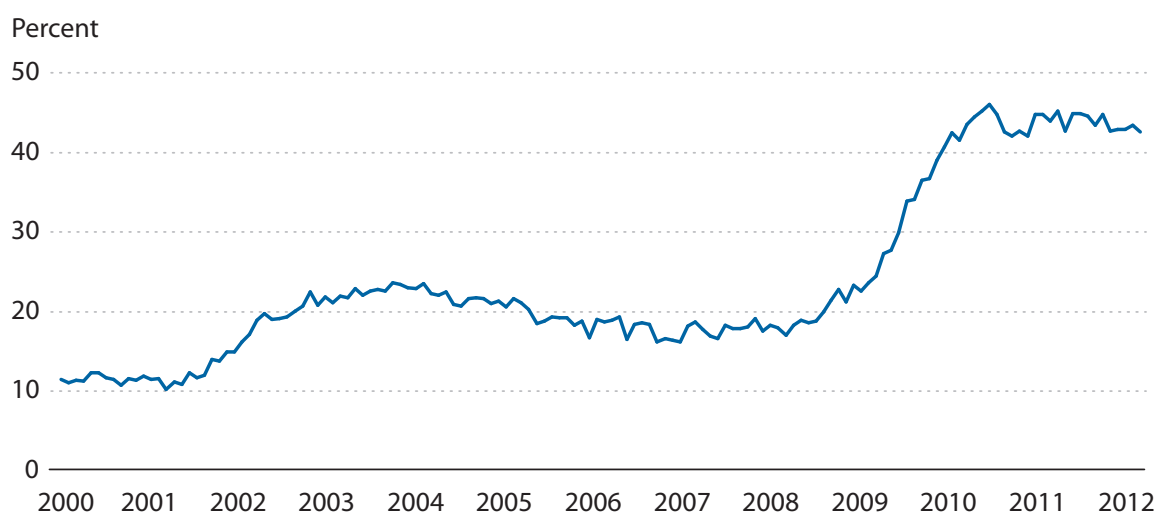

SOURCE: Bureau of Labor Statistics (as of February 29, 2012). 
El-Erian

\section{Table 1}

\section{How the Fed's Posture Has Changed}

March 15, 2011, FOMC Minutes

"Economic recovery is on a firmer footing"

"The Committee would continue its planning for the eventual exit from the current, exceptionally accommodative stance of monetary policy"

"Evidence of a stronger recovery...could make it appropriate to reduce the pace or overall size of the purchase program"

"Will pay close attention to the evolution of inflation and inflation expectations"

\section{January 24-25, 2012, FOMC Minutes}

"Economic activity continued to expand moderately, while global growth appeared to be slowing"

“Extending the horizon of the Committee's forward guidance would help provide more accommodative financial conditions"

"Current and prospective economic conditions...could warrant the initiation of additional securities purchases before long"

"The statement specifies a numerical inflation goal" of 2 percent

NOTE: The minutes of FOMC meetings are on the Board of Governors website (March 15, 2011, meeting: www.federalreserve.gov/monetarypolicy/fomcminutes20110315.htm; January 24-15, 2012, meeting: www.federalreserve.gov/monetarypolicy/fomcminutes 20120125 .htm).

able to turbocharge the equity markets as well as the markets for other risk assets (e.g., high-yield bonds). It has also simultaneously influenced the market for U.S. Treasury securities (Figure 5) via financial repression (Reinhart and Rogoff, 2009). The problem related repeatedly to the transmission to the real economy. Despite higher valuations, the hoped-for impact on economic activity, be it through the wealth effect or "animal spirits," has not materialized in the anticipated scale and scope.

The situation in Europe has been even more disappointing. Most economic and financial indicators in the countries with the most intense crises, particularly Greece, have fallen far short of program expectations. As a result, it has taken time for official intervention to reduce regional contagion risk. And it is not just countries such as Italy and Spain that were affected and faced the risk of liquidity disruptions turning into solvency problems. The disruptions also extended to the core of the euro zone as France lost one of its AAA ratings and credit default swap spreads also widened there and in other core economies (Figure 6). Even the region's powerhouse, Germany, risks some erosion in its ability to reap the fruits of years of sustained structural reforms.

Europe's slowness in dealing decisively with its debt crisis means that some banks there continue to confront legitimate questions about asset quality and capital adequacy. And while the ECB took care earlier this year of most of the liquidity concerns through generous facilities, this measure alone cannot fully restore the normal functioning of the European banking system or ensure depositor confidence.

This landscape does not speak to the willingness and ability of central banks. Rather, it relates to the limited effectiveness that comes from the inevitability of having to deploy an imperfect, and at times experimental, policy toolkit in the face of substantial and unusual challenges. 


\section{Figure 5}

\section{Effect of Fed Accommodation on Equities and U.S. Treasury Securities}

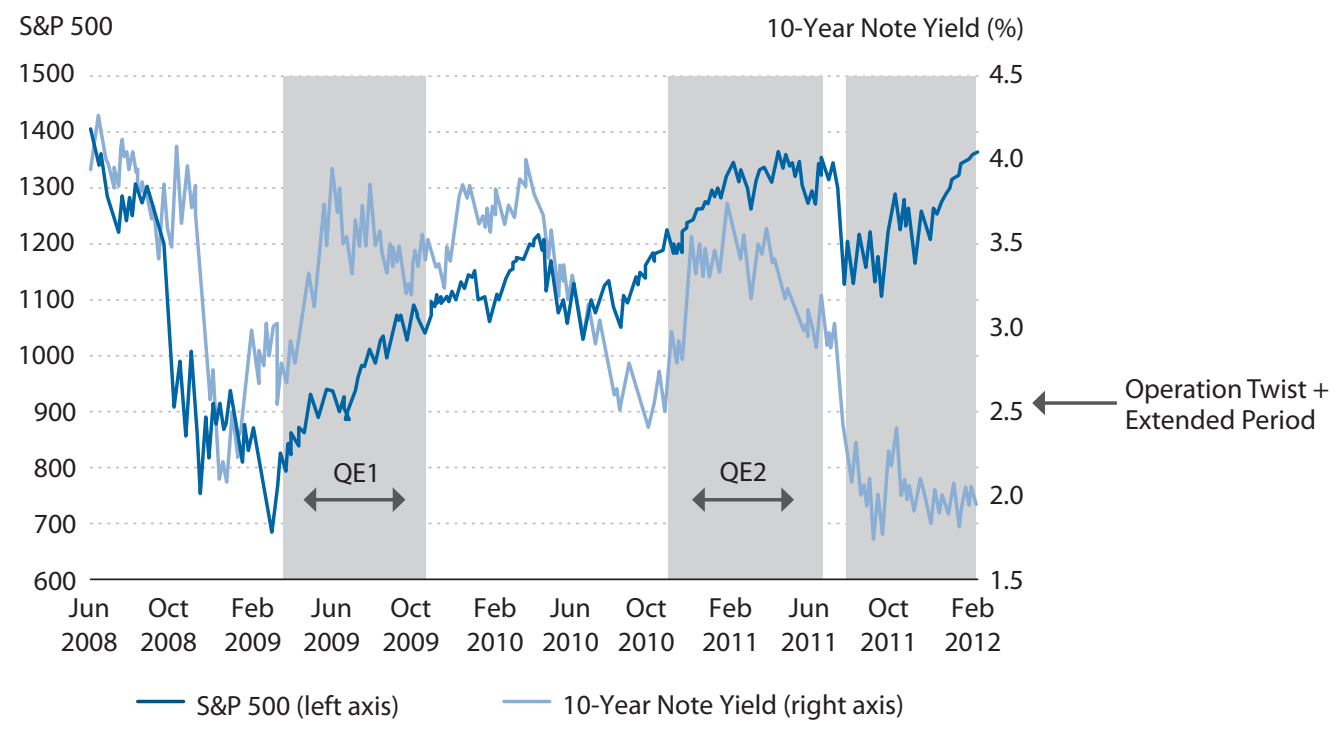

SOURCE: Bloomberg.

Figure 6

Five-Year Sovereign CDS Spreads

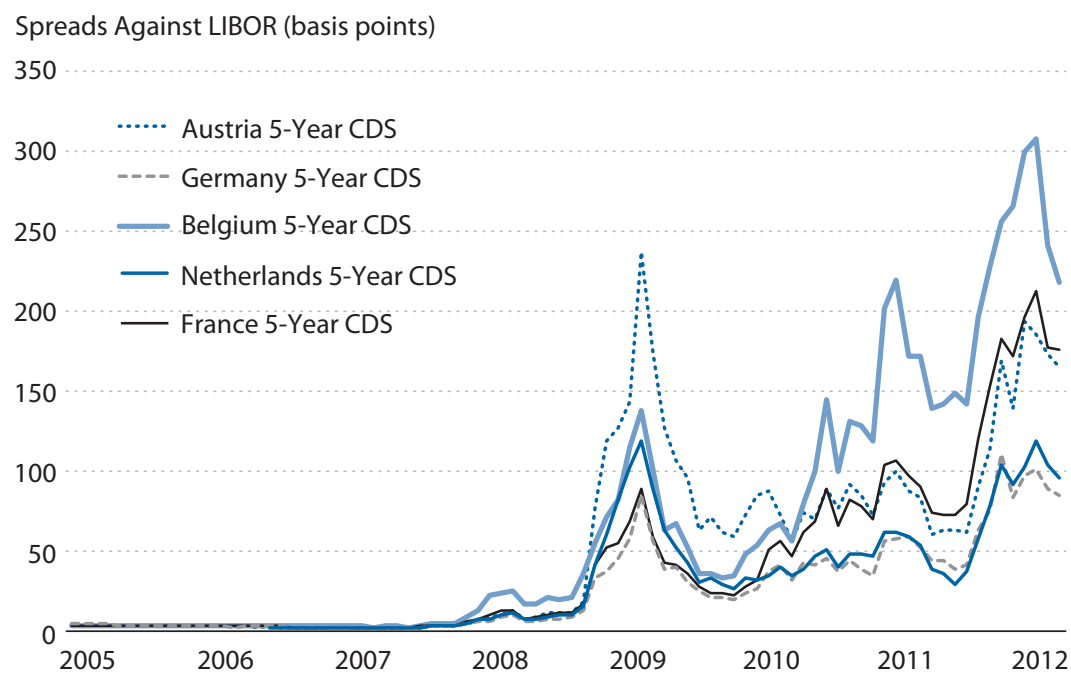

NOTE: CDS, credit default swap; LIBOR, London interbank offering rate.

SOURCE: Bloomberg, Markit (as of February 13, 2012). 


\section{THE REALITY}

While central banks can-and have-stabilized a range of malfunctioning financial markets, there is little they can do on their own to engineer the fundamental realignments that must accommodate seven specific dynamics in advanced economies (something we will return to later in discussing the way forward):

1. accommodating the "safe" debt deleveraging of the private sector by enabling high sustained growth

2. safely "de-risking" the financial sector

3. clearing or replacing clogged credit pipes

4. achieving a sustainable trajectory for public finances

5. improving the functioning of the labor market

6. compensating for inadequate past investments in human resources, productive capacity, and infrastructure

7. adjusting to the ongoing developmental breakout phase in several systemically important emerging countries (including Brazil, China, India, and Indonesia).

To be effective, central banks in advanced economies needed—and still need-help from other policymaking entities to confront the unfortunate twin reality of too much debt and too little growth. They must be assisted by the engagement of the healthy balance sheets around the world; fortunately, there are quite a few of them in both the public and private sectors. And this all must be done in an internationally coordinated fashion to accommodate the new global realities.

Central banks have received very little help—coordinated or otherwise-from other policy agencies. Moreover, until recently, too many of these agencies were inadvertently complicating the tasks of central banks. The contrast reflects a handful of factors:

- Many central banks - especially the Fed and the ECB — are endowed with an element of agility that most other entities, including fiscal agencies, lack. Autonomous/independent institutions can inherently move faster than elected fiscal chambers and most other regulatory agencies.

- Also, these fiscal and regulatory agencies have often failed to recognize the severity of the issues within their domain and to step up to the plate accordingly (such as in the areas of housing, housing finance, and public finance).

- Related to all this is the fact that few in government seem willing to make the range of required decisions with regard to the proper allocation of realized and prospective principal losses and, accordingly, the configuration of burden sharing.

- Faced with such difficult decisions, some political systems have shown more interest in bickering and dithering than coming together on key policy initiatives, thereby producing an unusually dysfunctional and paralyzing situation.

- The private sector has been unwilling to undertake sufficient long-term financial commitments in a world that is subject to so many moving economic, political, and regulatory pieces. 
These national failures were compounded by weak policy coordination at the global and regional levels. Finger-pointing replaced the harmony achieved at the G-20 meeting in April 2009 in London. This unfortunate situation was accentuated by a distinct lack of common analysis, as well as an IMF that is still too structurally impaired and lacking sufficient legitimacy to fully step in to fill the void.

Europe was hobbled by an additional element—challenges to a "unified sovereign" process that results in cumbersome decisionmaking among, first, the 17 members of the euro zone and, second, the larger European Union collective. This political reality has severely delayed meaningful early progress toward dealing with problems not adequately considered in the establishment of the euro zone. And, as hard as it has tried, the ECB does not have the ability to influence what at times is a dysfunctional political discussion among the politicians.

\section{THE OUTCOMES: BENEFITS, COSTS, AND RISKS}

Combine all these elements and it should come as no surprise that, having spectacularly succeeded in avoiding a global depression, central banks have subsequently faced difficulties in delivering their desired economic and financial outcomes. Yet they essentially have continued on the same policy path, raising the question of whether they are subject to the trap of "active inertia."

As argued by Dan Sull (1999), active inertia has historically tripped many successful companies and poses a constant threat to others. Faced with a paradigm shift, companies respond but too often do so on the basis of what ends up being an outmoded and ineffective mind-set.

Importantly, what is at play here is not the inability to recognize a paradigm change in a timely basis; nor is it the lack of appreciation that action is needed. Rather it is the combination of such factors as inadequate strategic framing and inappropriate anchoring. The result is understandable difficulty in adjusting the set of approaches, procedures, and conventional wisdoms that previously had served the institution well.

Although central banks have succeeded in sharply curtailing the catastrophic risk of a global depression, continuation of unusual policy activism now carries risks that extend beyond the inability to deliver good economic outcomes. There are also genuine concerns that such activism involves a range of collateral damage and unintended consequences, only some of which are visible at this stage. And central banks will be questioned about whether such activism continues to be justified, given the resulting (disappointing) impact on the overall economy.

There are already visible changes to the characteristics and functioning of certain markets. As an example, consider what is happening to the money markets segment.

With policy interest rates floored at zero for such an extended period (past and also prospectively, according to recent FOMC statements; see FOMC press release, 2012a), this segment will continue to shrink - and will do so mostly from the supply side. Funds are being reintermediated to the banking sector, with a substantial portion ending up in excess reserves at the Fed. In the process, borrowers that previously depended on money market investors (think here of commercial paper issuers as an example) now need to find alternative sources of funding.

The pension industry is also increasingly challenged. At current rates, the extent of underfunding is becoming even more systemic and is being only partially compensated by the increase 
in equity prices. This situation will accelerate a discussion that will be held in many circles in advanced economies: how to deal with the host of promises made at a very different economic time and that can no longer be fully met.

The functioning of markets is also changing given the size and scope of central bank involvement. The result is artificial pricing, lower liquidity, and a more cumbersome price discovery process. Moreover, participants will tell you that there are signs that the intermediaries have shifted a meaningful part of their balance sheet availability away from making markets for private sector clients to positioning for both the public sector's primary issuance and buyback activitiesa perfectly rational move given that the latter has more certainty at a time of general uncertainty.

Every time central banks buy government bonds, they do more than alter the duration of financial assets held by the private sector (and credit/default risk in the specific case of the ECB's SMP). In the case of three institutions in particular (the Bank of England, the Bank of Japan, and the Fed), they also modify the balance between "safe" and other assets in the financial system (Barclays, 2012). This change has implications for collateral flows and values, as well as market positioning.

There are also implications for the behavior of market participants. The essence here was captured well in a recent investor remark reported by Bloomberg: "Investors are numb and sedated... [by the] money sloshing around the system" (Detrixhe and Krause-Jackson, 2012).

When we discuss the impact on the functioning of markets, it is important to remember that, in game theoretic terms, central banks are "noncommercial players." Their motivations and objectives differ from those of other market participants that are driven by profit and loss considerations. They pursue noncommercial objectives; they possess a printing press at their command; and they have "structural patience" that far exceeds the ability of any other participants to remain in the trade. As such, their large involvement in markets cannot but alter their functioning and what constitutes rational behavior on the part of participants.

As demonstrated in an earlier graph (see Figure 5), the previously widespread notion of a "Greenspan put" for equities has now been replaced with that of a "Bernanke put" for both equities and bonds. You will thus find a significant number of investors referring to the repeated revealed preference of the Fed as an indication that the institution is de facto committed to supporting asset valuations until they are warranted by fundamentals. In Europe, ECB-influenced moral hazard trades seem quite prevalent based on casual empiricism, especially after the LTROs.

Put differently, a view has evolved that the "trading" segment of markets, whose focus is understandably short term, is now dominating the longer-term "investment" segment. This is consistent with data on market activity, how cash is allocated, and the succession of "risk on" and "risk off" sentiment. The problem with this view for the economy relates to the risk that capital allocation is distorted on both sides of the Atlantic.

I suspect that businesses and investment committees around the world are spending an unusual amount of time discussing what central banks are likely to do next. In too many cases, this discussion may overshadow those on fundamental trends, product design, and relative value opportunities. In the meantime, the incentive to self-insure against certain outcomes increases, making it harder to sustainably crowd-in long-term capital. $\underline{6}$

The recurring willingness of central banks to inject liquidity is also seen by some as a contributor to higher commodity prices, especially oil and precious metals-if not directly, then 


\section{Figure 7}

\section{U.S. 10-Year Breakevens}

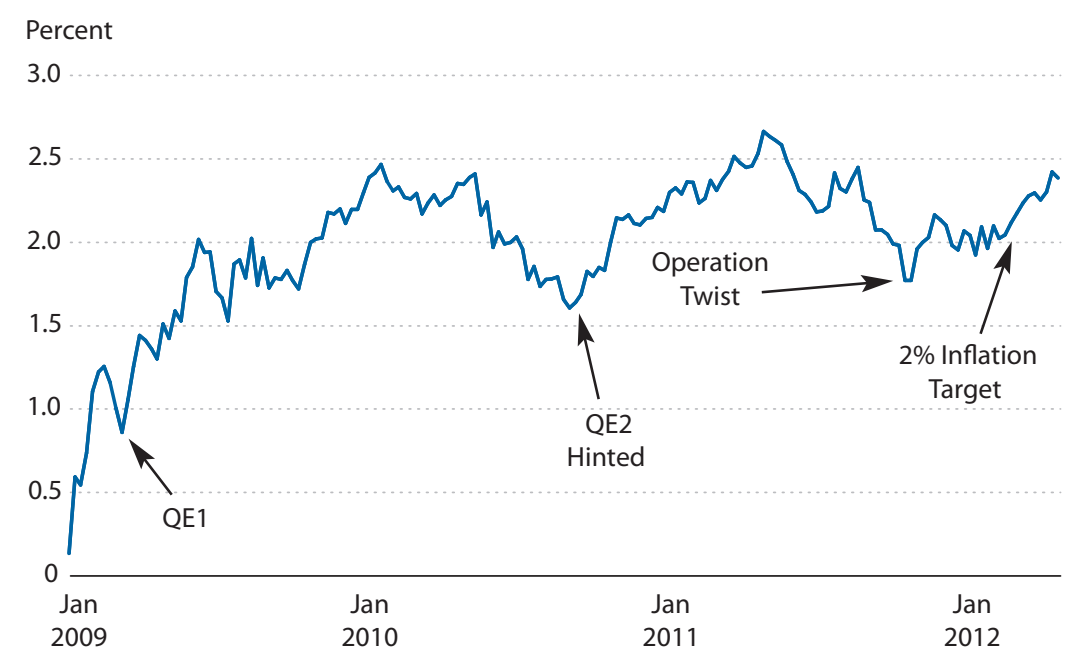

NOTE: The 10-year breakevens are calculated by subtracting the real yield of the inflation-linked maturity curve from the yield of the closest nominal Treasury maturity. The result is the implied inflation rate for the term of the stated maturity.

SOURCE: Bloomberg (as of March 23, 2012).

indirectly by encouraging a move of financial investments into the "real asset category," which also includes Treasury inflation-protected securities (TIPS; see Figures 7 and 8 for related moves in inflation breakevens and real rates). As real and perceived risks of liquidity-induced inflation rise, more investors also opt for commodities in the hope of protecting real purchasing power. As a result, in targeting "good inflation" (namely, higher asset prices that, in turn, lead to greater investment and consumption and, accordingly, better economic outcomes), central banks have been accused of contributing to "bad inflation" (including stagflationary headwinds caused by higher commodity prices) and, ultimately, greater challenges to consumption, investment, growth, and job creation.

As the sizable liquidity injections cannot be fully absorbed, there is always the risk that they "leak" through the balance of payments. Indeed, several emerging economies have vocally complained about surges in capital inflows that severely complicate their own domestic economic management. The result is an intensification of currency pressures for countries such as Brazil that have already warned of the risk of a "currency war."

A recent article in the Wall Street Journal noted, "In Brazil, the government officials blame the U.S. and Europe for lowering interest rates, and sending a wave of speculative cash its way, overvaluing its currency and hurting its competitiveness" (Lyons and Davis, 2012, p. A8). Indeed, the greater the activism of the Fed (in particular), the greater the dilemma facing other countries: They either follow the Fed or resist, but at the risk of larger distortions to their own economy.

Martin Wolf (2010), the highly respected economic commentator at the Financial Times, elegantly posed the dilemma as follows a couple of years ago: Given the opposing initial conditions for advanced countries and emerging ones, a policy tug-of-war was likely to develop in 


\section{El-Erian}

\section{Figure 8}

\section{Global 10-Year Real Yields}

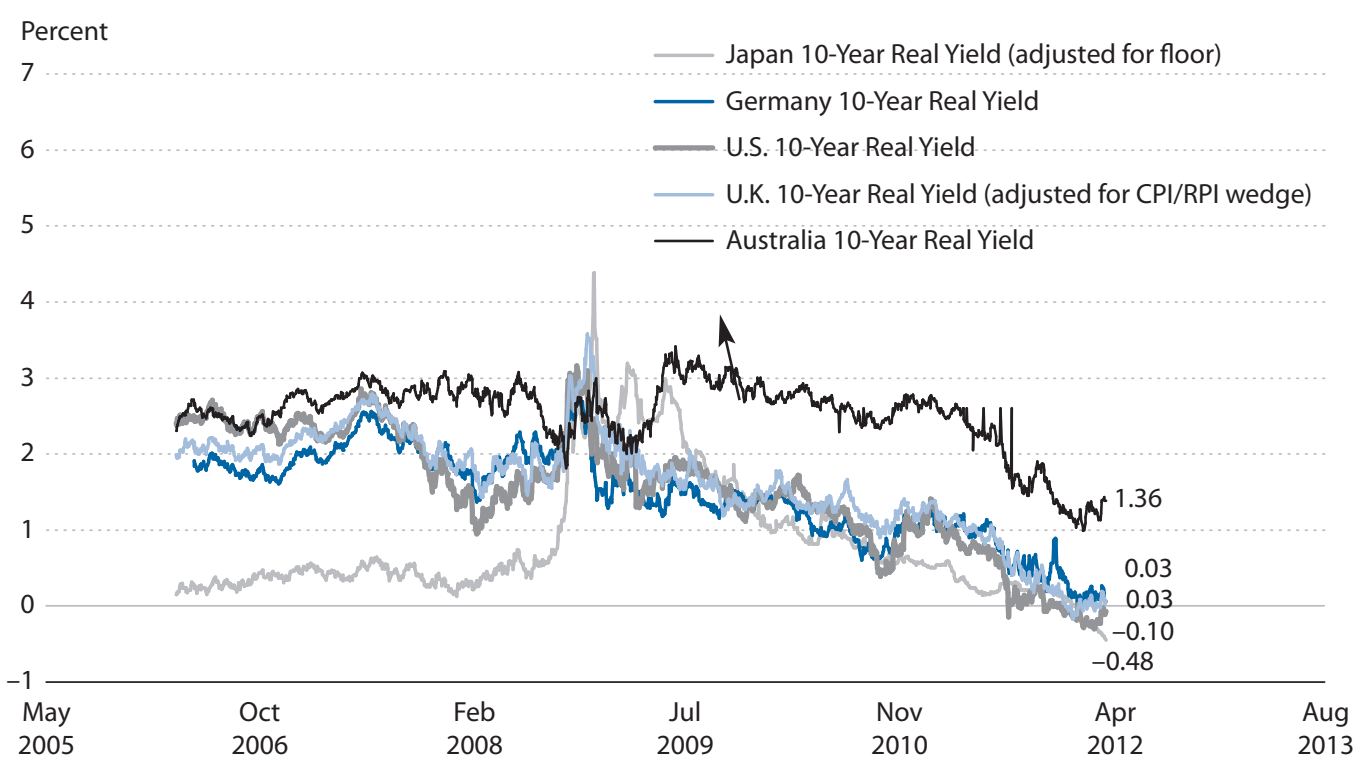

NOTE: Japan: Japanese inflation-linked bond (JPGi) 10-year yield (adjusted for floor); US: U.S. generic government (TII) 10-year yield; Australia: ACGBi 10-year yield; Germany: DBRei 10-year yield; U.K.: UKTI 10-year (adjusted for CPR/RPI [consumer price index/retail price index] wedge). SOURCE: Bloomberg (as of March 23, 2012).

which the Fed would seek to de facto force a reluctant and resisting rest of the world into reflation. This would be faced initially by resistance which, de facto, involves deflationary forces.

According to Wolf (2010), this is a contest that America would win. And, so far, he is correct. A number of central banks have found themselves joining the de facto QE parade. For advanced countries, this has included both Switzerland and Japan. In the case of the former, it has involved a dramatic tweak to the "brand" of the country as the "safe haven" for financial assets; and in the case of the latter, it has involved a central bank whose governor had left no doubt in the past about his feelings about QE (see Shirakawa, 2012, and El-Erian, 2011).

Emerging economies have also been forced into monetary easing-often seen there as the "less bad" of a series of unfortunate choices prompted by advanced countries' central banks continuing to act "irresponsibly" (and certainly in a manner that was deemed inappropriate by the IMF and the United States when the emerging economies faced their own dislocations in the 1980s, mid- and late 1990s, and early 2000s). In recent weeks, we have seen a series of monetary policy easing, including measures by Brazil, Chile, China, India, Indonesia, the Philippines, Vietnam, and others.

More controversial is what happens to credit at the zero bound-something that my colleague and PIMCO's founder, Bill Gross, has been writing about recently (see, for example, Gross, 2012a,b). At some stage, zero rates combined with residual risk premiums shift inward the supply of loanable funds to such an extent that it undermines maturity extension and the 
willingness to take on credit and liquidity risk. Zero rates also serve to complicate security lending, further undermining the plumbing operations that support liquidity and the sound functioning of markets.

Finally - and most controversial - the unusual activism of central banks may, at the margin, have worsened further wealth distribution. This has to do with the distribution and composition of financial wealth - in absolute terms and relative to labor income. To the extent that such policy activism succeeds in bolstering asset valuations but not the real economy, the rich benefit disproportionately more than the poor.

\section{THE REACTION FUNCTION AND POSSIBLE MOTIVATIONS}

So far, there is only limited evidence that these factors are affecting the behavior of central banks. This is not to say that recognition is lacking. It is not.

Some central banks, including the Fed and the Bank of England, have signaled their understanding of these costs and risks. This is particularly the case for the impact on pensions, money markets, and savers who rely on fixed incomes.

In the case of the Fed, Chairman Bernanke has noted that the FOMC is looking at these factors. He has added, however, that such negative externalities should be considered in the context of the need to heal the overall economy and return it to a path of high and sustained growth (see also Raskin, 2012). And the Fed has successfully cut off the horrid left tail of a debt and price deflation; that success speaks to the importance of considering such macro issues.

The case of the Bank of England could well be more nuanced at this stage. There has been active speculation about what prompted the Bank of England to announce on February 10 of this year $£ 50$ billion in additional purchases of gilts coupled with a reduction in targeted duration. Was it an improving domestic outlook, or was it the damage inflicted on the pension industry by the previous QE programs, as well as the scale of gilts already on the central bank's balance sheet?

Then there is the ECB. The dynamics there are much more complicated, especially as the constituent national central banks hold a range of views (and are subject to increased balance sheet dispersion). What is undeniable is the repeated discomfort expressed by Germany's Bundesbank, the most influential of the national banks. At times, this has resulted in public tensions with the ECB, as has the vocal involvement of politicians from both core and peripheral countries.

So, what explains the willingness of central banks to persist with an approach that, first, has disappointed in terms of outcomes and, second, is associated with such a range of collateral damage and unintended consequences? Many sitting here today are much better placed to answer this question. Indeed, analysts and observers would greatly welcome your insights on this. In the meantime, let me share with you some of the chatter in the marketplace and its implications.

\section{LET US RECOGNIZE UP FRONT WHAT IS NOT IN PLAY}

The lack of recognition by central banks that they are still far from a "first-best" policy is not at issue here. Instead, they are using imperfect instruments to deal with difficult and highly 
unusual challenges. This is reflected in numerous comments made by officials on both sides of the Atlantic.

It has been suggested that the main driver of the unusual central bank activism is the combination of two factors: first, the overwhelming priority of avoiding a global economic depression and financial meltdown and, second, the belief that the response to uncertainty should not be paralysis. Together they call for repeated policy experimentation, including the incremental adaptations of the policy instruments that are available.

It has also been suggested that, with other essential policymakers missing in action (or, in the specific case of Europe, insufficiently and inconsistently engaged), it would be morally and ethically wrong for central banks to also remain on the sidelines-especially as they enjoy much greater operational flexibility and, importantly, are subject to fewer short-term checks and balances from the political system.

Finally, some argue that the central banks have reason to believe that their actions will be followed by appropriate activism on the part of other government agencies, as well as the engagement of healthy balance sheets residing in the private sector. As such, central banks' bridges will prove effective.

I suspect that most, if not all, of these factors are in play. But they are associated with a considerable risk - that of maintaining an approach that is declining in expected net benefits yet continues to take pressure off other agencies (and politicians), all of whom are more than happy to leave the central banks in the spotlight. They are being let off the hook. Rather than be viewed as having a shared responsibility, these entities would rather have central banks be perceived as owning the solution to a really complex configuration of economic, financial, institutional, political, and social challenges.

\section{LOOKING FORWARD}

Turning from the past and present to the future, three hypotheses are worth noting up front:

1. There are reasons to believe that we may be nearing the limits of net effectiveness when it comes to the current set of central bank policies.

2. Simultaneously and not unconnected, several advanced economies may be experiencing a morphing of the probability curve for expected macroeconomic outcomes-from the past of a traditional bell-shaped curve to the present of a flatter distribution with fatter tails to a bimodal distribution.

3. Regardless of how reality materializes relative to the bimodal morphing of expected outcomes, we still face some major legacy issues, the consequences of which are, as yet, difficult to specify with a sufficient degree of conviction and foundation.

Whether in the United States or Europe, government yield curves are essentially floored at exceptionally low rates up to around the 5- to 7-year point (arguably the segment of the yield curve that has the most impact on economic activity). It is also increasingly uncertain whether, at the current set of market valuations, central banks can rely just on asset purchase programs as a means of enticing investors into doing things that they would not be doing on the basis of fundamentals. Sustainability for investors is more a function of being pulled into an investment 
because of its inherent attractiveness rather than being pushed into it by central banks' artificial manipulation of relative prices. Finally, there is the political angle. The unusual activism of central banks, especially components that are viewed as quasi-fiscal operations, is naturally attracting greater attention; there have been calls to subject these operations to greater parliamentary oversight, through de facto or, in some cases, de jure mechanisms.

All this comes at a time when we should expect the collateral damage of central bank activism to increase. As noted earlier, this is a multifaceted issue, involving the well-being of certain sectors, the viability of historic contracts and perceived entitlements, and the very functioning of markets. And while we do not know where the exact tipping points are, few wish to get too close to them.

To put it bluntly, there are now multiple reasons to worry about the risk of central banks' expensive (and expansive!) policy bridges ending up as bridges to nowhere. In other words, there is a growing possibility that, absent mid-course corrections, unsustainability may be the common characteristic of the central banks' unusual policy activism.

Please recall the earlier discussion (see "The Reality," p. 252) of the seven dynamics driving the fundamental structural realignments facing advanced economies. This is the economic context in which central banks need to pivot from the unsustainable to the sustainable. And to do so, they urgently need (i) the cooperation of other government entities that are better placed to address what are increasingly structural impediments to growth, jobs, and better income and wealth distribution and (ii) positively correlated behavior on the part of the private sector.

In the United States, Fed measures need to be supplemented by actions in the following key areas: the labor market, public finances, housing and housing finance, credit intermediation, education and investment in social sectors, and infrastructure. For the sake of brevity, let us focus here on a subset of these key areas.

While the unemployment rate has come down in recent months-and we can argue endlessly about how much was due to genuine job creation rather than an avoidable decline in the labor participation rate-it is hard to deny that rigidities are considerable, persistent, and consequential. $\underline{9}$

Recall that, according to the Bureau of Labor Statistics (2012), the number of long-term unemployed workers in the United States has been stuck at around 51/2 million. The longer the duration of joblessness, the greater the risk of skill erosion and the greater the headwinds to productivity and prosperity. Or note the worrisome indicator of youth unemployment. Some 24 percent of 16- to 19-year-olds in the labor force are unemployed; at that age, persistent joblessness can turn someone from being unemployed to being unemployable. Or note the sharp dispersion in the unemployment rates for different levels of education: from 4 percent for those with a bachelor's degree to 13 percent for those without a high school diploma.

Central bank actions cannot deal with these issues. Simply put, these institutions do not have the instruments or expertise to deal with the challenges of labor training and retooling. They cannot improve labor market flexibility and mobility. And they cannot influence the country's education system. Yet these challenges should-indeed must-be successfully confronted if we are to avoid the curse of unemployment becoming deeply embedded in the structure of the economy and, therefore, much harder to resolve. 
Put housing and housing finance in the same category of importance as the labor market. There will be no durable and healthy economic recovery unless America deals with an issue that affects wealth, labor mobility, market clearing dynamics, the rule of law, and the willingness of fresh capital to engage.

Once again, there isn't much that the Fed can do beyond advocacy (something that it has been doing via speeches and a white paper; see Board of Governors, 2012). We all have to look elsewhere for an actual set of durable and effective policy measures.

Then, of course, there is the state of public finances. This is critical to both the immediate and longer-term well-being of the country. Fed officials have not been shy in emphasizing the importance of striking the right balance between immediate stimulus and longer-term fiscal reform that involves both spending and taxes. Just a few weeks ago on the Hill, Chairman Bernanke warned Congress of the dangers of a massive fiscal cliff, as well as longer-term issues of fiscal sustainability (see, e.g., Schroeder, 2012). Yet, here again, advocacy alone does not seem to go far enough. America needs both the Treasury and its politicians, especially in Congress, to get much more serious.

The ECB is in a similar dilemma-indeed, more pronounced and certainly much more urgent. It cannot deliver debt solvency and international competitiveness to peripheral economies such as Greece. Unless it is helped by others, there is likely to be a limit out there to how long it can, on its own, stop a liquidity problem in Italy and Spain from raising concerns again about solvency. And it can advocate for a stronger euro zone core but can do little to secure, to use the former French President Nicolas Sarkozy's word, the "refounding" of Europe.

Whether the ECB officials like it or not-and I would venture they do not-history books will judge the success of their unusual activism based on what other policymakers end up doing. In the meantime, Europe, like too many other advanced economies, is experiencing a consequential morphing of the shape of the distribution for expected macroeconomic outcomes.

\section{EXPECTED DISTRIBUTION OF POSSIBLE OUTCOMES}

There is a good chance that much of policymaking - and clearly the important underpinnings of conventional portfolio management-is based on a traditional bell curve governing the distribution of expected outcomes. As some of my colleagues, including Rich Clarida and Vineer Bhansali, have written, things change quite a bit when this is no longer the case (see Clarida and El-Erian, 2010, and Bhansali, 2011).

The morphing of expectation distributions is most invasive in Europe. Given the extent to which the dislocations in the periphery have contaminated the core, it is hard to see how the euro zone can maintain the status quo of the past two years. Instead, one of two scenarios may play out over time. Either European leaders are able to regain control of the situation and put the "project" on a much stronger structural and financial footing (either in its current configuration or via a smaller, stronger, and more coherent one), or they risk losing total control and seeing this important construct fall victim to disorderly fragmentation with significant costs not only for Europe, but also for virtually every country around the world.

This potentially places the ECB in an equally unsettling bimodal situation. First, it can see its bold efforts of recent years supplemented and reinforced by better policymaking elsewhere, 
thereby also engaging fresh private sector capital that can serve as oxygen for the real economy and facilitate over time the resolution of the twin problem of too much debt and too little growth. Or, second, it may find itself having to help clean up a series of bank disruptions, a disorderly collapse in the demand curve for European assets (including government bonds), and, most worrisome of all, a messy return to national currencies.

The situation in the United States is less extreme, leaving the country for now more exposed to a "muddle through" scenario (though the underlying dynamics are not totally dissimilar). Policymakers here are in a better position to regain control of outcomes. By addressing the impediments listed earlier, they can encourage the engagement of significant idle private capital and place the economy back on the road to higher growth, greater job creation, financial soundness, and less-worrisome trends in income and wealth inequality. However, if they continue to dither and bicker, structural impediments will grow, will become more deeply entrenched in the construct of the economy, and will further undermine policy flexibility and effectiveness.

This bimodal situation has implications for Fed policy. In one mode, the Fed sees its unusual policy activism rewarded and ends up retaining sufficient popular and political support to allow it to pursue its dual objectives in an effective manner. In the other mode, the very independence of the Fed could be severely threatened and its policy activism could end up inadvertently associated with either stagflation or, even worse, debt deflation and recession.

What transpires in America and Europe is extremely consequential for virtually every country in the world and every market. It is not just about the largest two economic regions and, therefore, systemic demand and financial and network effects. It is also about the eventual construct of the global economy.

The functioning of today's global economy is still dominated by what is best described as a concentric circles construct. Despite its recent economic and financial challenges, the West occupies the inner circle and essentially anchors the outer circles. This Western-anchored core provides the major global public goods, has a disproportionate impact on policy agendas, and still dominates multilateral forums. While several of those in the outer circles have grown stronger and are even starting to link directly (e.g., through bilateral payments arrangements), none are in a position to move into the inner circle, nor do they wish to.

The traditional concentric construct underpinning the international monetary system persists if the weakening of the core is alleviated in the short term and meaningfully reversed over the longer term. This happens only if the Fed and ECB are supported in their policymaking role by other government entities - and supported in a manner consistent with the developmental breakout phase of systemically important emerging economies. Absent that, it is more likely that the world would undergo a messy transition to a multipolar construct whose functioning, as yet, is unclear and whose implications are uncertain though most certainly consequential.

\section{CONCLUDING REMARKS}

After diffusing a material threat of a global depression, central banks in the advanced economies did a good job in maintaining a certain status quo in the midst of too much debt, too little growth, too much inequality, and a historic global economic realignment. Critically, they succeeded in their overwhelming priority of avoiding an economic depression. Concurrently, 


\section{El-Erian}

they reduced the risk of market overshoots and disruptive multiple equilibrium dynamics, thereby alleviating well-founded concerns about extreme negative tail-risk events, including a renewed financial meltdown.

This success involved the unprecedented use of tools available to central banks. In the process, central banks stretched like never before in the era of modern central banking the very concept of a monetary institution. And while the benefits were immediate in the crisis management phase, they have been less consistent when it comes to securing certain economic outcomes. In addition, they have come at a potential cost and with risks. They are also serving to alter behavioral relationships, change market functioning, and modify the configuration of certain market segments.

I think that we have reached the legitimate point of - and the need for-much greater debate on whether the benefits of such unusual central bank activism sufficiently justify the costs and risks. This is not an issue of central banks' desire to do good in a world facing an "unusually uncertain" outlook. Rather, it relates to questions about diminishing returns and the eroding potency of the current policy stances.

Fundamentally, what is increasingly in play today is the set of challenges facing central banks' toolkit in a world that also confronts meaningful structural (as opposed to just cyclical) and solvency headwinds. This is about the balance between continued benefits and unintended consequences/collateral damage. It also speaks to the extent to which the crutches of unusual central bank activism risk being treated as substitutes for actions by other policymaking entities, politicians, businesses, and capital markets. In sum, it is about the concept of sustainabilitynot only for economies but also for central banks as healthy, credible, and politically robust institutions in our national, regional, and global economies.

Where the global economy goes from here will depend less on the actions of central banks and more on whether others, including key government entities and private sector participants that have the ability to act but lack sufficient willingness to do so, finally step up to the plate. Only with the supportive actions of others can central banks pivot away from using-again, in my own clumsy terms - "the unsustainable to sustain the unsustainable" and move toward a better equilibrium for them and for the global economy (i.e., sustainability).

This need for others to step up to the plate does not mean that central banks are off the hook. Quite the contrary. In the period ahead, central banks will need to consider how best to navigate what may increasingly morph over time into a bimodal distribution for expected economic outcomes, especially in Europe. They could also find themselves countering even more complicated self-insurance behavior on the part of the private sector. And the political context could get more difficult.

Rather than lead the parade of advanced nations-which they have done so skillfully and boldly since the outbreak of the global financial crisis-central banks risk finding themselves increasingly in the position of followers. And they will do so in the context of uncertainties about the overall construct of a global economy that is now operating with a weaker traditional core but no ready and able substitutes.

The welfare of millions in the United States and Europe, if not billions of people around the world, will have suffered greatly if central banks end up in the unpleasant position of having to clean up after a parade of advanced nations that headed straight into a global recession and a 
disorderly debt deflation. Let us therefore hope that central banks will, instead, find themselves part of a much broader policy effort headed toward high sustainable growth, ample job creation, less income and wealth inequality, and financial soundness.

\section{NOTES}

1 I am grateful to Paul McCulley, my former PIMCO colleague, for first alerting me of this delicate balance.

2 Bernanke (2010a) warned of the unusually uncertain outlook during his July 21, 2010, appearance before the Senate Banking, Housing, and Urban Affairs Committee.

3 Bernanke (2010b, p. 12) referred to this balance-among benefits, costs, and risks—at the 2010 Jackson Hole Symposium; he also cited the balance in subsequent papers and testimonies.

4 This paper does not deal with the role of central banks in the run-up to the 2008 global financial crisis.

$\underline{5}$ The concept of sudden stops was popularized by Professor Guillermo Calvo in the context of the 1980s Latin American crisis; see Calvo (1993).

6 Note that all this is consistent with the changes in asset class correlations in capital markets.

7 See, for example, the comments by Finance Minister Guido Mantega in Wheatley and Leahy (2011).

$\underline{8}$ For a recent analysis of concerns with activism, and for the case for restoring some of the old orthodoxy, see Plosser (2012). Part of this perspective is countered in another paper presented at this meeting - namely, McCulley and Pozsar (2012).

9 For example, see El-Erian (2012b). A more detailed recent analysis is contained in Bernanke (2012).

\section{REFERENCES}

Barclays Capital. Equity Gilt Study 2012. Fifth-seventh edition. Barclays Bank PLC, London, 2012.

Bernanke, Ben. Semiannual Monetary Policy Report to the Congress. Testimony before the Committee on Banking, Housing, and Urban Affairs, U.S. Senate, Washington, DC, July 21, 2010a; www.federalreserve.gov/newsevents/testimony/bernanke20100721a.htm.

Bernanke, Ben. "The Economic Outlook and Monetary Policy." Presented at a symposium sponsored by the Federal Reserve Bank of Kansas City, "Macroeconomic Challenges: The Decade Ahead," Jackson Hole, Wyoming, August 27, 2010b; www.federalreserve.gov/newsevents/speech/bernanke20100827a.htm.

Bernanke, Ben. "Recent Developments in the Labor Market." Speech to the National Association for Business Economics Annual Conference, Washington, DC, March 26, 2012; www.federalreserve.gov/newsevents/speech/bernanke20120326a.htm.

Bhansali, Vineer. "Asset Allocation and Risk Management in a Bimodal World." Viewpoints, December 2011, PIMCO; www.pimco.com/EN/Insights/Pages/Asset-Allocation-and-Risk-Management-in-a-Bimodal-World.aspx.

Blanchard, Olivier. “Blanchard on 2011's Four Hard Truths.” VOX, December 23, 2011; www.voxeu.org/index.php?q=node/7475.

Board of Governors of the Federal Reserve System. "The U.S. Housing Market: Current Conditions and Policy Considerations." White paper, January 4, 2012; http://federalreserve.gov/publications/other-reports/files/housing-white-paper-20120104.pdf.

Bureau of Labor Statistics. "The Employment Situation—January 2012." News release. February 3, 2012; www.bls.gov/news.release/pdf/empsit.pdf.

Calvo, Guillermo A. "Explaining Sudden Stop, Growth Collapse, and BOP Crisis." IMF Staff Papers, Special Issue 1993, 50, pp.1-20; www.imf.org/external/pubs/ft/staffp/2002/00-00/pdf/calvo.pdf.

Clarida, Richard and El-Erian, Mohamed. "Uncertainty Changing Investment Landscape." Financial Times, August 20, 2010; www.ft.com/intl/cms/s/0/3ff03d10-9e53-11df-a5a4-00144feab49a.html\#axzz1 toQLvubw. 


\section{El-Erian}

Cohen, Michael A. “The Powell Doctrine's Enduring Relevance." World Politics Review, July 22, 2009; www.worldpoliticsreview.com/articles/4100/the-powell-doctrines-enduring-relevance?page=1.

Detrixhe, John and Krause-Jackson, Flavia. "Iran Anxiety No Match for Central Bankers Sedating Investors." Bloomberg News, February 8, 2012; www.bloomberg.com/news/2012-02-08/iran-anxiety-no-match-for-central-bankerssedating-traders-with-cheap-cash.html.

El-Erian, Mohamed A. "Learning from the 'Lost Decades,"' in Clay Chandler, Heang Chhor, and Brian Salsberg, eds., Reimagining Japan. San Francisco: VIZ Media, 2011, pp. 108-13.

El-Erian, Mohamed A. "The Fed Explains Its Big Adventure." Financial Times, February 16, 2012a; http://blogs.ft.com/the-a-list/2012/02/16/the-fed-explains-its-big-adventure/\#axzz1tjCQTZJm.

El-Erian, Mohamed A. "Still Losing the War on Unemployment." WP Opinions (blog), Washington Post, February 5, 2012b; www.washingtonpost.com/opinions/us-unemployment-war-needs-more-help-from-lawmakers/2012/02/02/ glQAkQYmmQ story.html.

El-Erian, Mohamed A. and Spence, Michael A. "Systemic Risk, Multiple Equilibria and Market Dynamics—What You Need to Know and Why." Viewpoints, PIMCO, March 2012; http://latam.pimco.com/EN/Insights/Pages/SystemicRisk,-Multiple-Equilibria-and-Market-Dynamics-What-You-Need-to-Know-and-Why-.aspx\#.

Federal Open Market Committee. Press Release. January 25, 2012; www.federalreserve.gov/newsevents/press/monetary/20120125a.htm.

Gross, William H. "Life-and Death Proposition." Investment Outlook (blog), PIMCO, February 2012a; www.pimco.com/EN/Insights/Pages/Life-and-Death-Proposition.aspx.

Gross, William H. "Zero-Based Money Is at Risk of Trapping the Recovery." Markets Insight (blog), Financial Times, February 6, 2012b; www.ft.com/intl/cms/s/0/ad537e88-4ccd-11e1-8741-00144feabdc0.html\#axzz1 toQLvubw.

Lyons, John and Davis, Bob. “Emerging-Market Engines Falter." Wall Street Journal, March 8, 2012, p. A8.

McCulley, Paul and Pozsar, Zoltan. “Does Central Bank Independence Frustrate the Optimal Fiscal-Monetary Policy Mix in a Liquidity Trap?" Presented at the Inaugural Meeting of the Global Society of Fellows of the Global Interdependence Center, "Re-Examining Central Bank Orthodoxy for Unorthodox Times," Banque de France, Paris, March 26, 2012; www.interdependence.org/wp-content/uploads/2012/03/Paul-McCulley-Fellows-Paper.pdf.

Plosser, Charles I. "Restoring Central Banks after the Crisis." Presented at the Inaugural Meeting of the Global Society of Fellows of the Global Interdependence Center, "Re-Examining Central Bank Orthodoxy for Unorthodox Times," Banque de France, Paris, France, March 26, 2012; www.philadelphiafed.org/publications/speeches/plosser/2012/03-26-12 global-interdependence-center.pdf.

Raskin, Sarah Bloom. "Accommodative Monetary Policy and Its Effects on Savers." Speech to the Y's Men and Y's Women of Westport, Westport, Connecticut, March 1, 2012; www.federalreserve.gov/newsevents/speech/raskin20120301a.htm.

Reinhart, Carmen and Rogoff, Kenneth S. This Time Is Different: Eight Centuries of Financial Folly. Princeton, NJ: Princeton University Press, 2009.

Schroeder, Peter. "Bernanke Warns Lawmakers Country Headed for Massive Fiscal Cliff." On the Money (blog), The Hill, February 29, 2012; http://thehill.com/blogs/on-the-money/801-economy/213351-fed-boss-warns-of-massive-fiscal-cliff.

Shirakawa, Masaaki. "Deleveraging and Growth: Is the Developed World Following Japan's Long and Winding Road?" Lecture at the London School of Economics and Political Science, January 10, 2012; www.boj.or.jp/en/announcements/press/koen_2012/data/ko120111a.pdf.

Sull, Donald N. “Why Good Companies Go Bad.” Harvard Business Review, July-August 1999, pp. 42-52.

Wheatley, Jonathan and Leahy, Joe. "Trade War Looming, Brazil Says." Financial Times, January 10, 2011; www.ft.com/intl/cms/s/0/6316eb4a-1c34-11e0-9b56-00144feab49a.html\#axzz1 toQLvubw.

Wolf, Martin. "Why America Is Going to Win the Global Currency Battle." Financial Times, October 12, 2010; www.ft.com/intl/cms/s/0/fe45eeb2-d644-11df-81f0-00144feabdc0.html\#axzz1 toQLvubw. 
Close

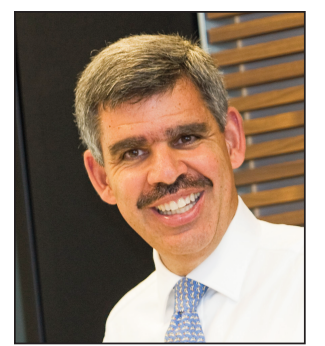

Mohamed A. El-Erian

CEO and co-CIO, Pacific Investment Management Co. LLC (PIMCO)

\section{Research Focus}

Mohamed El-Erian's research focuses on macroeconomic policy issues, financial markets, and debt solvency. 